\title{
Agreement of antenatal care indicators from self-reported questionnaire and the antenatal care card of women in the 2015 Pelotas birth cohort, Rio Grande do Sul, Brazil
}

Lina Sofia Morón-Duarte ${ }^{1 *}$ (D, Andrea Ramirez Varela ${ }^{1}$, Diego G. Bassani ${ }^{2}$, Andrea Dâmaso Bertoldi ${ }^{1}$, Marlos R. Domingues ${ }^{1}$, Fernando C. Wehrmeister ${ }^{1}$ and Mariangela Freitas Silveira ${ }^{1}$

\begin{abstract}
Background: Studies of healthcare service use during the pregnancy-postpartum cycle often rely on self-reported data. The reliability of self-reported information is often questioned as administrative data or medical records, such as antenatal care cards, are usually preferred. In this study, we measured the agreement of antenatal care indicators from self-reported information and antenatal care cards of pregnant women in the 2015 Pelotas Birth Cohort, Brazil.

Methods: In a sample of 3923 mothers, indicator agreement strengths were estimated from Kappa and prevalenceand-bias-adjusted Kappa (PABAK) coefficients. Maternal characteristics associated with indicator agreements were assessed with heterogeneity chi-squared tests.
\end{abstract}

Results: The self-reported questionnaire and the antenatal care card showed a moderate to high agreement in 10 of 21 (48\%) antenatal care indicators that assessed care service use, clinical examination and diseases during pregnancy. Counseling indicators performed poorly. Self-reported information presented a higher frequency data and a higher sensitivity but slightly lower specificity when compared to the antenatal card. Factors associated with higher agreement between both data sources included lower maternal age, higher level of education, primiparous status, and being a recipient of health care in the public sector.

Conclusions: Self-reported questionnaire and antenatal care cards provided substantially different information on indicator performance. Reliance on only one source of data to assess antenatal care quality may be questionable for some indicators. From a public health perspective, it is recommended that antenatal care programs use multiple data sources to estimate quality and effectiveness of health promotion and disease prevention in pregnant women and their offspring.

Keywords: Agreement, Antenatal care, Indicators, Antenatal card, Self-reported questionnaire

\footnotetext{
* Correspondence: sofismodu@gmail.com

${ }^{1}$ Post-Graduate Program in Epidemiology, Federal University of Pelotas, Rua

Marechal Deodoro 1160 - Centro, Pelotas, Rio Grande do Sul 96020-220,

Brazil

Full list of author information is available at the end of the article
}

(c) The Author(s). 2019 Open Access This article is distributed under the terms of the Creative Commons Attribution 4.0 International License (http://creativecommons.org/licenses/by/4.0/), which permits unrestricted use, distribution, and reproduction in any medium, provided you give appropriate credit to the original author(s) and the source, provide a link to the Creative Commons license, and indicate if changes were made. The Creative Commons Public Domain Dedication waiver (http://creativecommons.org/publicdomain/zero/1.0/) applies to the data made available in this article, unless otherwise stated. 


\section{Background}

Antenatal Care (ANC) comprises a number of activities and procedures aimed at preserving the health of pregnant women while ensuring delivery of preventive measures, early detection of complications and the adequate management of pre-existing maternal disease states [1]. The reduction of maternal mortality remains a priority under "Goal 3: Ensure healthy lives and promote wellbeing for all at all ages" in the new Sustainable Development Goals (SDGs) agenda through 2030 [2]. In this context, information on maternal and child health is fundamental to ensure antenatal care quality and reduction of maternal and perinatal mortality. In Brazil, a pregnancy card records health information and details of antenatal and postpartum care visits. The card is a tool included in the Prenatal and Birth Humanization Program, part of the Ministry of Health medical record systems, and its use is mandatory to ensure that healthcare for pregnant women meets the national minimum quality standards. The card includes information on ANC visits, diagnostic findings and patient behaviors and links the different stages of the health care process. The systematic collection of data during each consultation can therefore be used to provide optimal health services at any point of care.

An alternative method for collection of data on health care received during the pregnancy-postpartum cycle is the use of individual questionnaires. The in-person interview or questionnaire is frequently used in epidemiology research because it provides a comprehensive and standardized assessment of the topic of interest. It is a relatively inexpensive tool that enables collection of data from a large population sample.

Medical records are considered the gold standard and are generally the preferred data source over interviews/ questionnaires. However, evidence indicates that reliability of any individual source of data is imperfect, possibly inaccurate, and thus the combination of sources may improve reliability and completeness of information [1,3-6]. The objective of this study was to evaluate for the first time the agreement between self-reported questionnaire information and data recorded in the ANC cards from women in the 2015 city of Pelotas Birth Cohort study, Rio Grande do Sul, Brazil.

\section{Materials and methods Study settings}

The data is representative of births in the municipality of Pelotas in 2015. However, this birth cohort is not representative of the total number of births in Brazil for that period. In 2015, 5598 newborn babies were identified, of whom 4329 were children of mothers who were residents in the urban area of Pelotas (cohort study targeted population) and were invited to participate. The refusal rate was $1.3 \%$ in the perinatal period.

\section{Sampling}

This was a cross-sectional study based on the mothers of children eligible for the 2015 Pelotas Birth Cohort who were interviewed during pregnancy and/or at birth. The total number of eligible pregnant mothers was 4329 (in the case of multiple pregnancies only one record was kept for each mother). Fifty-nine records corresponded to multiple births, totaling 4270 mothers in the birth cohort. Of these mothers 4172 had attended ANC but 249 did not have an antenatal card available at the time of interview, resulting in a final sample of 3923 mothers included in this study (Additional file 1: Figure S1).

The questionnaires used during prenatal and perinatal visits of the 2015 Pelotas Birth Cohort are available at http://epidemio-ufpel.org.br/site/content/coorte_2015/ questionarios.php. More detailed information on the cohort methods and follow-up visits is provided elsewhere [7].

\section{Variables}

The information was collected through interviews during pregnancy and/or the perinatal period. During antenatal care, two antenatal visits were performed, one before gestational week 16 and the second between gestational weeks 16 and 24. The third follow-up was at delivery. One questionnaire was used at weeks 16,24 and at delivery to collect sociodemographic characteristics including maternal age, education, marital status, skin color, family income, pre-pregnancy health, and if the mother was seen by the same health professional during ANC and type of ANC provider. The perinatal questionnaire asked for reproductive health history variables - delivery characteristics, number of pregnancies, and if the mother was seen by the same health professional during ANC and type of ANC provider. ANC data were also collected at delivery and documented service utilization, details of clinical examination, occurrence of disease during pregnancy, prophylactic interventions (vaccination and supplements), and educational interventions (counseling). Additional file 2: Table S1 shows the questionnaire contents and data collection tools.

At the end of the interview the ANC card was photographed and information on ANC routines extracted and double entered into a database (Epi Info 6.04, Centers for Disease Control and Prevention, Atlanta, USA) by two trained research assistants. A consistency analysis with a frequency verification was performed using Stata $12^{\circ}$ (Statacorp, College Station, TX, USA).

If there was no record of a given procedure on the card, it was considered as not performed. The agreement analysis was carried out only when the card was available with at least one record present. The questionnaire 
items and antenatal card variables used in this study are described in Additional file 3: Table S2.

\section{Statistical analysis}

The agreement between the card and the questionnaire for each variable of interest was estimated using Kappa coefficient ( $\mathrm{k}$ ) with corresponding 95\% confidence intervals (95\% CI). Kappa and Prevalence-Adjusted-and-Bias-Adjusted Kappa (PABAK) [8] values were interpreted using Landis and Koch categorization [9] into almost perfect $(>0.80)$, substantial $(0.61-0.80)$, moderate $(0.41-0.60)$, fair $(0.21-0.40)$, slight $(0.00-0.20)$ and poor $(<0.00)$. Sensitivity and specificity are reported with $95 \% \mathrm{CI}$ and were calculated assuming the ANC card to be the gold standard or assuming the questionnaire to be the gold standard.

The association of maternal characteristics with an agreement between the card and the questionnaire was evaluated by building a score ranging from 1 to 10 using those ANC indicators with adjusted Kappa coefficients in the categories of almost perfect to moderate (ten indicators as shown in Table 3). A value of 1 was assigned to each indicator agreement $(1=$ yes/yes or no/no). The score was dichotomized into low ( $\leq 7$ points as zero) and high agreement ( $\geq 8$ points as one) to conduct bivariate analysis using the score as the dependent variable. Heterogeneity chi-squared tests were used to measure the difference between low and high agreement categories. The analyses were performed in Stata $15^{\circ}$ (Statacorp, College Station, TX, USA).

\section{Results}

\section{Sample characteristics}

Within the cohort of 3923 women $82.6 \%$ were between 20 and 39 years of age, $14.4 \%$ were under 20 years of age, $71.9 \%$ were white, $33.7 \%$ had up to 8 years of schooling and $86.4 \%$ were living with a partner at the time of interview. With regard to socioeconomic data, $59.7 \%$ were between the first and third quintiles of family income. In relation to obstetrical data, $50.4 \%$ of the women were primiparous, $64.8 \%$ had undergone c-section delivery, $52.8 \%$ were seen by the same health professional during ANC, and $45.0 \%$ received ANC in the public health sector. When comparing our sample with mothers who did not attend or receive ANC and lacked an antenatal card, a statistically significant difference for maternal education, marital status, family income, and parity was found (Table 1). Table 2 shows the distribution of data from ANC cards and from the self-reported questionnaire.

\section{Agreement between ANC card indicators and questionnaire information}

From the 21 indicators in the ANC card we observed that agreement strength with self-reported questionnaire information was poor in 1 indicator $(K<0.00)$, slight for
16 ( $\mathrm{K}$ between $0.00-0.20$ ), fair for 2 ( $\mathrm{K}$ between $0.21-0.40$ ), and moderate for 2 (K between 0.41-0.60) (Table 3). The agreement strength category obtained with the PABAK was higher than that obtained with the Kappa coefficient in 9 (43\%) indicators - antenatal care number of visits $\geq 6$, reported date of last menstrual period, weight, symphysisfundal height, blood pressure, syphilis test, hypertension during pregnancy, diabetes during pregnancy, and sexually transmitted diseases (Table 3). Agreement strength categories for urinary tract infection during pregnancy, breast exam, hepatitis B vaccination, and counseling on physical activities such as walking were moderate, slight, fair, and poor respectively, and were equally categorized by PABAK and Kappa values. Agreement strength categories were lower with PABAK relative to those obtained with Kappa for gynecological exam, cervical cancer screening test, counseling on risks of alcohol use during pregnancy and counseling on risks of smoking during pregnancy (Table 3).

\section{Sensitivity and specificity \\ Self-reported questionnaire with the ANC card as the gold standard}

The sensitivity of the self-reported questionnaire was high $(>90 \%)$ for $28.6 \%$ of the indicators evaluated, all of them in the components of service use and clinical examination. Good sensitivity $(\geq 80$ and $<90 \%)$ was present in $23.8 \%$ and low sensitivity $(<80 \%)$ in $47.6 \%$ of the indicators. Specificity was low $(<80 \%)$ for all indicators except for diabetes and sexually transmitted diseases that had $>90 \%$ specificity (Table 4 .).

\section{Antenatal card with the self-reported questionnaire as the gold standard}

The sensitivity of antenatal card was high (>90\%) for $19.0 \%$ of the indicators evaluated, all of them in the clinical examination component. The number of visits showed good sensitivity (81.1\%) and the rest presented low sensitivity. Specificity was high for $42.8 \%$ of the indicators, mainly those related to diseases during pregnancy and counselling. Good specificity $(\geq 80$ and $<90 \%)$ was present in $19.0 \%$ of the indicators (Table 4 ).

\section{Maternal factors associated with an agreement between data sources}

Table 5 presents the maternal characteristics associated with the concordance between the ANC card and self-report questionnaire. There was a significantly higher agreement among pregnant women with younger age, more years of maternal schooling, primiparous status and those using a public sector health care provider. 
Table 1 Maternal characteristics in the 2015 Pelotas Birth Cohort, Brazil

\begin{tabular}{|c|c|c|c|}
\hline Characteristics & Mothers with ANC and card $(n=3923) \mathrm{n}(\%)$ & Mothers without ANC or card $(n=346) \mathrm{n}(\%)$ & Chi-squared test $p$ value \\
\hline \multicolumn{4}{|l|}{ Age (years) } \\
\hline$\leq 19$ & $565(90.0)$ & $63(10.0)$ & \multirow[t]{4}{*}{0.144} \\
\hline $20-29$ & $1.878(92.7)$ & $147(7.3)$ & \\
\hline $30-39$ & $1.365(91.6)$ & $125(8.4)$ & \\
\hline$\geq 40$ & $115(91.3)$ & $11(8.7)$ & \\
\hline \multicolumn{4}{|c|}{ Maternal education (complete years of schooling) } \\
\hline $0-4$ & $337(85.5)$ & $57(14.5)$ & \multirow[t]{4}{*}{$<0.001$} \\
\hline $5-8$ & $985(89.7)$ & $113(10.3)$ & \\
\hline $9-11$ & $1.388(94.9)$ & $75(5.1)$ & \\
\hline $12+$ & $1.213(92.3)$ & $101(7.7)$ & \\
\hline \multicolumn{4}{|l|}{ Marital status } \\
\hline Without partner & $535(86.4)$ & $84(13.6)$ & \multirow[t]{2}{*}{$<0.001$} \\
\hline With partner & $3.388(92.8)$ & $262(7.2)$ & \\
\hline \multicolumn{4}{|l|}{ Skin color } \\
\hline White & $2.824(92.5)$ & $230(7.5)$ & \multirow[t]{3}{*}{0.086} \\
\hline Black & $586(90.2)$ & $64(9.8)$ & \\
\hline Other & $513(90.8)$ & $52(9.2)$ & \\
\hline \multicolumn{4}{|c|}{ Family income (quintiles) } \\
\hline Lowest/first & $759(88.5)$ & 99 (11.5) & \multirow{5}{*}{$\leq 0.001$} \\
\hline Second & $784(91.8)$ & $70(8.2)$ & \\
\hline Third & $802(93.6)$ & $55(6.4)$ & \\
\hline Fourth & $803(93.7)$ & $54(6.3)$ & \\
\hline Highest/fifth & $774(91.9)$ & $68(8.1)$ & \\
\hline \multicolumn{4}{|l|}{ Type of delivery } \\
\hline Normal & $1.378(91.2)$ & $133(8.8)$ & \multirow[t]{2}{*}{0.217} \\
\hline C-section & $2.545(92.3)$ & $213(7.7)$ & \\
\hline \multicolumn{4}{|l|}{ Parity } \\
\hline Primiparous & $1.977(93.5)$ & $137(6.5)$ & \multirow[t]{2}{*}{$<0.001$} \\
\hline$\geq 2$ children & $1.945(90.3)$ & $209(9.7)$ & \\
\hline \multicolumn{4}{|c|}{ ANC consultation by same professional } \\
\hline Yes & $2.074(93.4)$ & $147(6.6)$ & \multirow[t]{2}{*}{0.059} \\
\hline No & $1.849(94.8)$ & $102(5.2)$ & \\
\hline \multicolumn{4}{|c|}{ Type of health care provider } \\
\hline Public & $1.372(98.6)$ & $20(1.4)$ & \multirow[t]{3}{*}{0.175} \\
\hline Private & 1.203 (97.6) & $30(2.4)$ & \\
\hline Others & 472 (97.9) & $10(2.1)$ & \\
\hline
\end{tabular}

For some variables, the number of subjects does not add up to the total of the subjects included due to missing information

\section{Discussion}

Main findings

To our knowledge, this is one of the few studies evaluating the agreement between self-reported questionnaire from pregnant women and the antenatal card that recorded procedures and interventions during ANC [10, 11]. The assessment of agreement between sources of information on $\mathrm{ANC}$ assistance is an issue that has aroused the interest of the global scientific community. Our key findings indicate firstly, that assessment of ANC from self-reported questionnaire has moderate to high agreement to ANC card indicators of service utilization, clinical examination and diseases during pregnancy whereas indicators of counseling performed poorly. Secondly, self-reported information presented higher data frequency and higher sensitivity but slightly lower specificity when compared to 
Table 2 Distribution of ANC indicator data by information source

\begin{tabular}{|c|c|c|c|c|}
\hline \multirow[b]{3}{*}{ Indicator } & \multicolumn{4}{|l|}{ Source } \\
\hline & \multicolumn{2}{|l|}{ ANC card } & \multicolumn{2}{|l|}{ Self-reported } \\
\hline & Yes n (\%) & No n (\%) & Yes n (\%) & No n (\%) \\
\hline Report of the number of antenatal care visits $(\geq 6)$ & $2703(71.1)$ & $1101(28.9)$ & $3373(86.3)$ & $536(13.7)$ \\
\hline Report of the last date of menstrual period & $2852(72.7)$ & $1071(27.3)$ & $3887(99.1)$ & $35(0.9)$ \\
\hline \multicolumn{5}{|l|}{ Clinical exams } \\
\hline Weight measurement & $3781(96.4)$ & $142(3.6)$ & $3914(99.8)$ & $8(0.2)$ \\
\hline Symphysis-fundal height measurement & 3666 (93.5) & $257(6.5)$ & $3903(99.5)$ & $19(0.5)$ \\
\hline Blood pressure measurement & $3782(96.4)$ & $141(3.6)$ & $3921(99.9)$ & $2(0.1)$ \\
\hline Gynecological exam & $1391(35.5)$ & $2534(64.5)$ & $3355(85.5)$ & $567(14.5)$ \\
\hline Cervical cancer screening test & $737(18.8)$ & $3186(81.2)$ & $2526(64.5)$ & $1388(35.5)$ \\
\hline Dental exam & $186(4.7)$ & $3737(95.3)$ & $1412(36.0)$ & $2510(64.0)$ \\
\hline Breast exam & $657(16.8)$ & $3266(83.3)$ & $1821(46.5)$ & $2096(53.5)$ \\
\hline Venereal disease research laboratory (VDRL) test & $3579(91.2)$ & $344(8.8)$ & 3916 (99.8) & $7(0.2)$ \\
\hline \multicolumn{5}{|l|}{ Diseases during pregnancy } \\
\hline Hypertension & $43(1.1)$ & $3880(98.9)$ & $1005(25.6)$ & $2917(74.4)$ \\
\hline Anaemia & $136(3.8)$ & $3288(96.3)$ & $1662(42.4)$ & $2259(57.6)$ \\
\hline Diabetes & $24(0.6)$ & $3899(99.4)$ & $348(8.9)$ & $3575(91.1)$ \\
\hline Urinary tract infection & $1256(32.0)$ & $2667(68.0)$ & $1782(45.5)$ & $2135(54.5)$ \\
\hline Sexually transmitted diseases & $111(2.8)$ & $3812(97.2)$ & $38(1.0)$ & $3881(99.0)$ \\
\hline \multicolumn{5}{|l|}{ Vaccination-Supplements } \\
\hline Tetanus toxoid vaccination & $2102(53.6)$ & $1821(46.4)$ & $2473(64.0)$ & $1393(36.0)$ \\
\hline Hepatitis B vaccination & $1312(33.4)$ & $2611(66.5)$ & $1973(51.4)$ & $1869(48.7)$ \\
\hline Iron supplements prescription & $991(25.3)$ & $2932(74.7)$ & $3100(79.0)$ & $823(21.0)$ \\
\hline \multicolumn{5}{|l|}{ Counselling } \\
\hline Risks of alcohol use during pregnancy & $38(1.0)$ & $3885(99.0)$ & $2919(74.5)$ & $1001(25.5)$ \\
\hline Risks of smoking during pregnancy & $46(1.2)$ & 3877 (98.8) & $2947(75.2)$ & $973(24.8)$ \\
\hline Physical exercises such as walking & $3(0.1)$ & $3920(99.9)$ & $2430(62.0)$ & $1491(38.0)$ \\
\hline
\end{tabular}

the ANC card. Thirdly, factors associated with higher agreement between both data sources included young maternal age, more maternal schooling years, being a primiparous mother, and health care received in the public sector.

\section{Moderate to high agreement on indicators of service utilization, clinical examination and diseases during pregnancy. Poor agreement on indicators of counseling}

The moderate to high agreement in these indicators suggests that assessment of ANC through selfreported questionnaire or the antenatal card could be equivalent. However, caution is advised when interpreting these results, especially for indicators related to diseases during pregnancy. As has been shown in other studies [12], the performance of antenatal clinical exams such as measurements of weight, symphysis-fundal height, and blood pressure reached almost perfect agreement $[10,12]$. These findings may be related to the ability of the patient to identify the reason for the ANC procedure/action recorded by the health professional during the ANC visit. For example, self-reporting weight may be more accurate than self-reporting a cervical cancer screening test. Patients are more likely to understand that weight is being measured when asked to step on a scale but less likely to discern whether a cervical cancer screening test is the reason for a gynecological examination [13-15]. Indeed we found a very low agreement on reporting of gynecological exam, cervical cancer screening test and breast exam (Table 3). Given that the frequency of these procedures was lower in the ANC cards relative to self-reports, the low agreements may also stem from poor record-keeping by health professionals or that these tests, that are mandatory at the national level, were not carried out, as reported in other studies [10-14, 16-23]. This would raise serious concerns regarding the quality of healthcare that women and their offspring receive. 


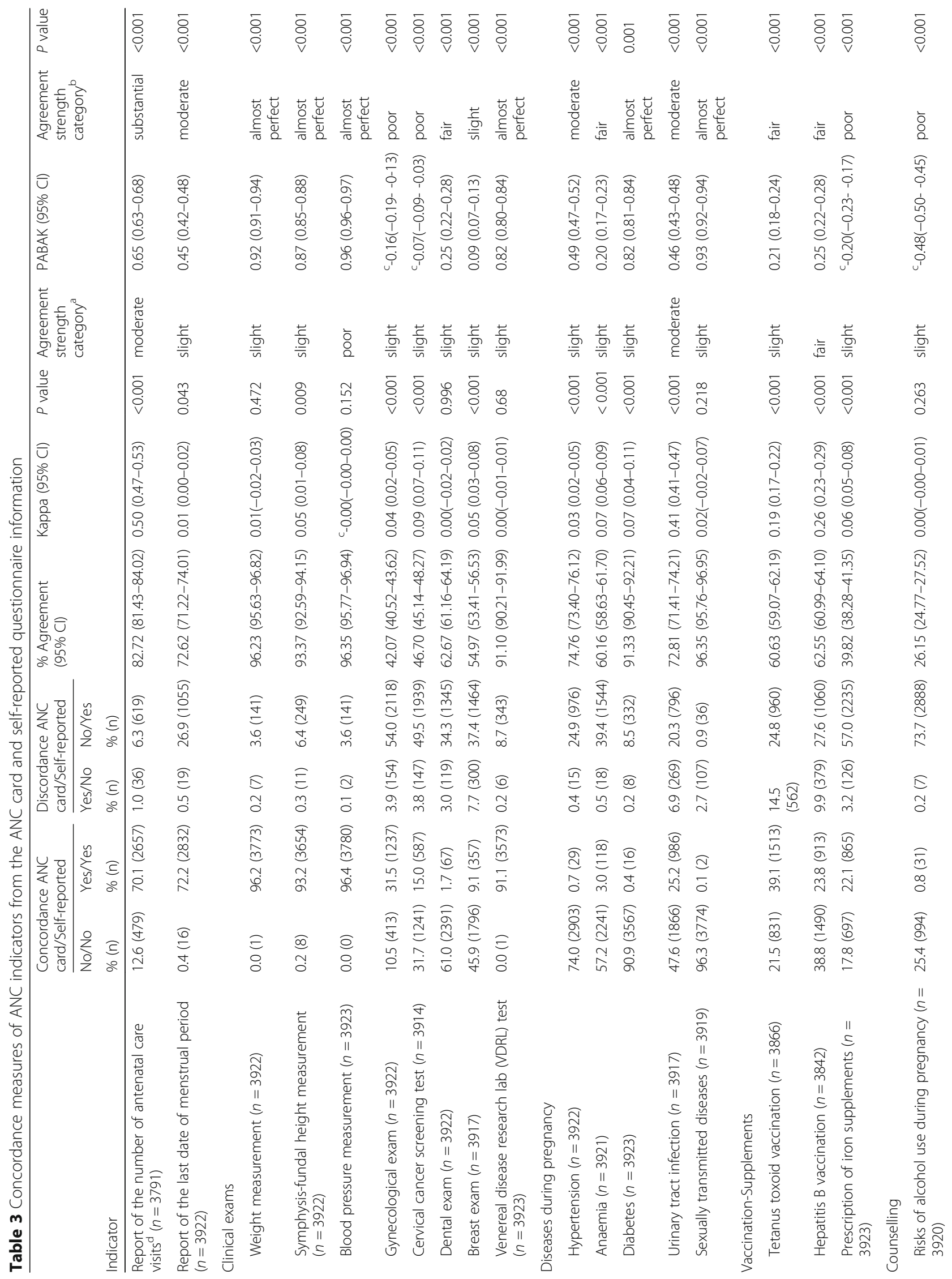




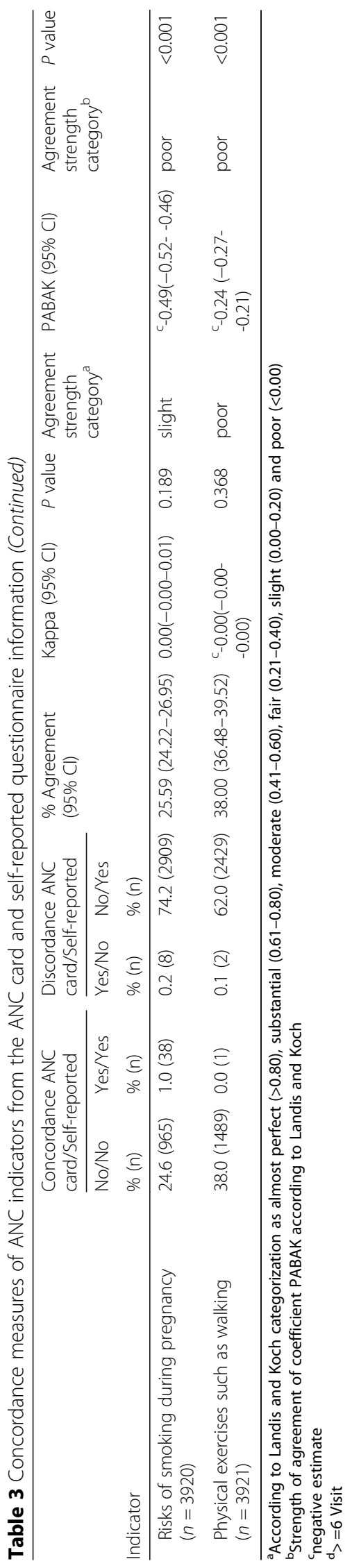




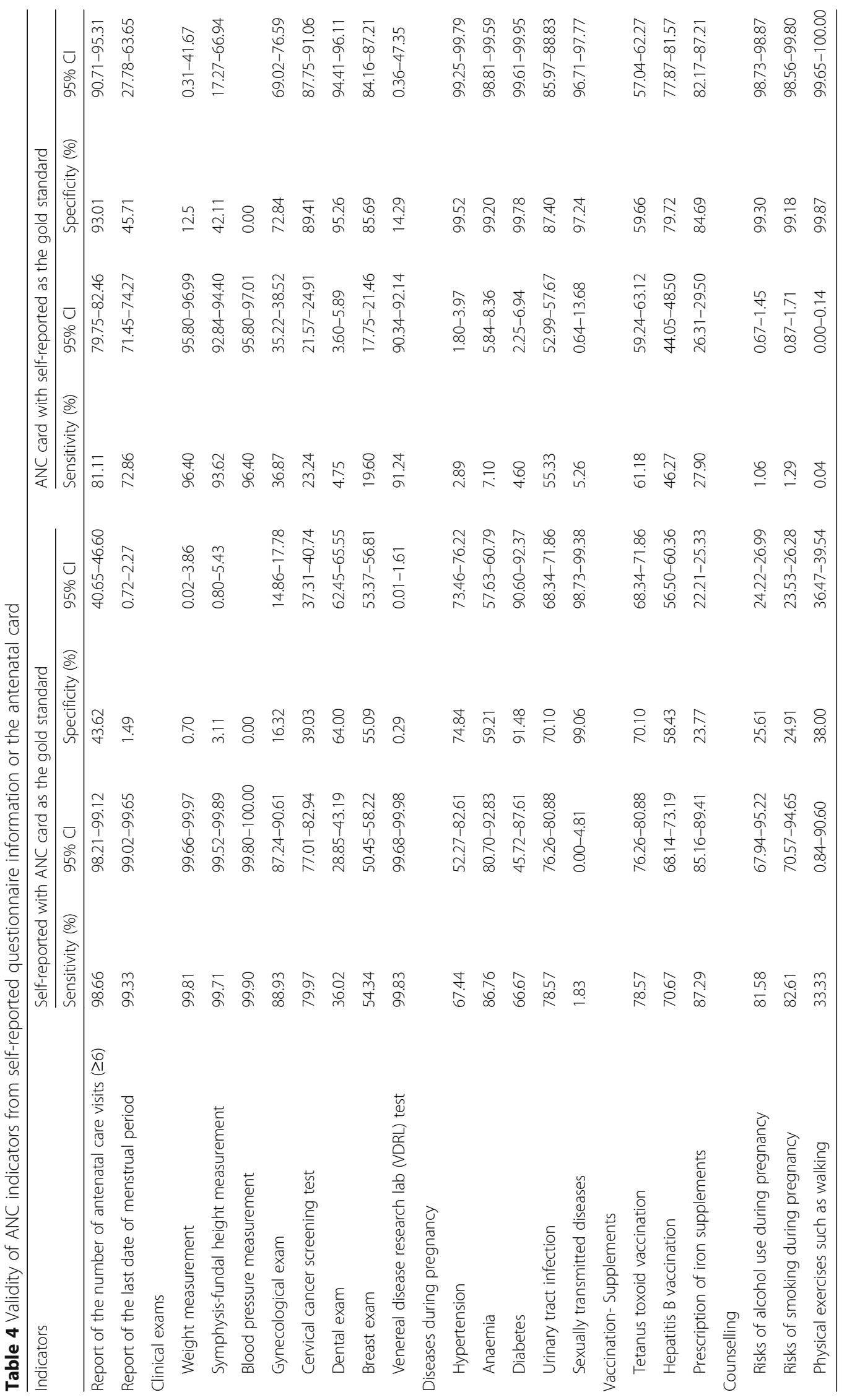


Table 5 Maternal characteristics associated with agreement between the ANC card and self-reported questionnaire

\begin{tabular}{|c|c|c|c|}
\hline Characteristics & Low $\mathrm{n}(\%)$ & High n (\%) & $\begin{array}{l}\text { Chi-squared test } \\
p \text { value }\end{array}$ \\
\hline \multicolumn{4}{|l|}{ Age (years) } \\
\hline$\leq 19$ & $85(15.0)$ & $480(85.0)$ & \multirow[t]{4}{*}{$<0.001$} \\
\hline $20-29$ & $272(14.5)$ & $1606(85.5)$ & \\
\hline $30-39$ & $252(18.5)$ & $1113(81.5)$ & \\
\hline$\geq 40$ & $38(33.0)$ & $77(67.0)$ & \\
\hline \multicolumn{4}{|c|}{ Maternal education (complete years of schooling) } \\
\hline $0-4$ & $76(22.6)$ & $261(77.5)$ & \multirow[t]{4}{*}{0.008} \\
\hline $5-8$ & $169(17.2)$ & $816(82.8)$ & \\
\hline $9-11$ & $207(14.9)$ & $1181(85.1)$ & \\
\hline $12+$ & $195(16.1)$ & $1018(83.9)$ & \\
\hline \multicolumn{4}{|l|}{ Marital status } \\
\hline Without partner & 99 (18.5) & $436(81.5)$ & \multirow[t]{2}{*}{0.177} \\
\hline With partner & $548(16.2)$ & $2840(83.8)$ & \\
\hline \multicolumn{4}{|l|}{ Skin color } \\
\hline White & $459(16.3)$ & $2365(83.8)$ & \multirow[t]{3}{*}{0.523} \\
\hline Black & $106(18.1)$ & 480 (81.9) & \\
\hline Other & $82(16.0)$ & $431(84.0)$ & \\
\hline \multicolumn{4}{|l|}{ Family income } \\
\hline Lowest/first & $144(19.0)$ & $615(81.0)$ & \multirow[t]{5}{*}{0,062} \\
\hline Second & $118(15.1)$ & $666(85.0)$ & \\
\hline Third & 125 (15.6) & $677(84.4)$ & \\
\hline Fourth & $147(18.3)$ & $656(81.7)$ & \\
\hline Highest/fifth & $113(14.6)$ & $661(85.4)$ & \\
\hline \multicolumn{4}{|l|}{ Type of delivery } \\
\hline Normal & $206(15.0)$ & $1172(85.1)$ & \multirow[t]{2}{*}{0.055} \\
\hline C-section & $441(17.3)$ & 2104 (82.7) & \\
\hline \multicolumn{4}{|l|}{ Parity } \\
\hline Primiparous & $298(15.1)$ & 1679 (84.9) & \multirow[t]{2}{*}{0.017} \\
\hline$\geq 2$ children & 348 (17.9) & 1597 (82.1) & \\
\hline \multicolumn{4}{|c|}{ The same professional performed the antenatal consultations } \\
\hline Yes & $341(16.4)$ & $1733(83.5)$ & \multirow[t]{2}{*}{0.928} \\
\hline No & $306(16.6)$ & $1543(83.5)$ & \\
\hline \multicolumn{4}{|c|}{ Type of health care provider } \\
\hline Public sector & $192(14.0)$ & $1180(86.0)$ & \multirow[t]{3}{*}{0.005} \\
\hline Private sector & $194(16.1)$ & 1009 (83.9) & \\
\hline Others & 96 (20.3) & 376 (79.7) & \\
\hline
\end{tabular}

Efforts to improve the quality of care for pregnant women in Brazil include a National Oral Health Policy [24] which mandates a dental consultation when initiating ANC. Our study found a fair agreement. However, the results should be analyzed with caution as $70.9 \%$ $(1002 / 1412)$ of the pregnant women who reported having consulted with a dentist during pregnancy also participated in the oral health sub-study of this cohort [7], therefore in the general population agreement could be lower than reported.

For gestational diabetes, agreement was classified as almost perfect, a finding confirmed by other studies [25, 26] where agreement was often higher than those reported for other chronic diseases [27, 28]. Studies evaluating selfreported medical information have shown that patients can provide reasonably good reports on their illnesses [29, 30]. Recent publications on urinary tract infection have shown moderate agreement between self-reporting and medical records with a low sensitivity [31, 32], similar to the findings obtained by our study.

Some conditions such as diabetes, hypertension, anemia, and urinary tract infection may not have been recorded on the ANC cards, but women still refer to having experienced them. Similar findings have been reported in other studies [10,33,34]. One possible reason for over reporting of gestational diabetes is that the diagnosis requires a positive result on two different glucose tests. Thus, women with a positive first test but negative on the second may have reported gestational diabetes. Sexually transmitted diseases may have been underreported possibly due to stigmatization.

Counselling indicators were more frequently selfreported than reported in the antenatal card. Reports of counselling pertaining to alcohol use and smoking during pregnancy had the lowest Kappa values and the highest difference between sources, perhaps due to a low probability of reporting of these habits to healthcare providers during antenatal care. Previous studies have shown that counseling and referrals (e.g., cervical cancer screening tests) are underreported in medical records compared to self-reported records, indicating that health professionals do not consistently register these interventions $[35,36]$.

\section{. Self-reported information presented higher data frequency and higher sensitivity but slightly lower specificity when compared to the ANC card}

The use of questionnaires in epidemiologic studies is considered a valid tool with many advantages for research. However, the quality of the information obtained by selfreporting is dependent on the type of disease [37, 38], the characteristics of the participants [30, 39], the design of the questionnaire, and the method used to administer it [40, 41]. In addition, information obtained by selfreporting or by review of medical records may not be consistent. Several studies have shown that the agreement between the two sources of information is dependent on the type of variable collected [42-44].

When self-report was compared to the card as gold standard, we found that specificity and sensitivity were $>$ $80 \%$ for $9.5 \%(2 / 21)$ and $52 \%(11 / 51)$ of ANC indicators 
respectively. The high sensitivity in this comparison may be related to the use of self-administered questionnaires as sources of information on exposures and outcomes, which may be more complete and with fewer omissions in responses by participants.

When we compared the antenatal card with self-report as the gold standard, we found that the specificity and sensitivity were $>80 \%$ for $60 \%(13 / 21)$ and $25 \%(5 / 21)$ of ANC indicators respectively. This high specificity suggests that data recorded on the cards corresponded to the most relevant aspects identified during medical consultation. The low sensitivity suggests that registration of other ANC procedures/activities was incomplete. One reason may be that data recorded on antenatal cards do not accurately reflect all events occuring during a medical visit $[45,46]$. Furthermore the content of antenatal cards is not standardized for data collection in a private versus public setting or designed for data collection by health professionals with responsibility for specific aspects of ANC.

Despite these limitations, data collected in the ANC card are preferable for making decisions on potentially significant clinical interventions during antenatal and perinatal stages [47].

\section{. Maternal characteristics associated with the agreement between the ANC card and the self-reported questionnaire} Sociodemographic characteristics may contribute towards the strength of agreement between data sources and determine ANC quality [48]. Our findings show that higher maternal age, lower educational status, pregnant women with $\geq 2$ children and type of healthcare provider associate with a lower probability of high agreement between the antenatal card and the self-reported questionnaire. We were unable to find other studies on factors associated with ANC indicator agreements for the data sources used in our study. However, there is evidence that the demand for health services and ANC quality are typically related to the sociodemographic characteristics of pregnant women [49].

\section{Limitations and implications}

Due to the intrinsic limitations of the data sources analyzed herewith, judgements about their respective validity should be made with caution.

The quality of medical record documentation may be affected by omissions in reporting, for example tests may have been performed elsewhere and not transcribed onto the antenatal card or incomplete documentation due to time constraints for record-keeping by health professionals. In addition to problems with recordingkeeping, accuracy of medical record extraction may be compromised by bias, fatigue or distraction of the systematic reviewer. These findings suggest that a purely quality-based assessment on medical records data could fail to find information on performed procedures and interventions that the pregnant woman might have supplied. This can result in the loss of important information on some ANC indicators.

The quality of an evaluation that depends solely on self-reported information can be influenced by recall bias, by subjectivity or misunderstanding of the questions pertaining to diagnoses, procedures and interventions received during ANC. In addition, the accuracy of a self-report may be affected by culturally influenced factors such as the importance of events, awareness and knowledge of health conditions [50].

\section{Conclusions}

Our study shows that data from questionnaires or the ANC cards provide substantially different information on indicator performance. From a public health perspective this raises questions with regard to reliance on indicators derived from a single data source. It may be more prudent to assess the quality of ANC programs using multiple data sources to determine quality and effectiveness of health promotion and disease prevention programs in pregnant women and their offspring. Researchers should explore alternative methods and data sources to obtain consistent estimates of ANC quality, various different indicators, be aware of factors that may influence the accuracy of data sources and conduct substudies to collect such data when not available. The implications of choosing a questionnaire or medical records should be carefully considered when evaluating health services for clinical practice, research, and public health. Deciding which data source to use will also depend on the outcome of interest and if the data is used for clinical decision-making, performance tracking, or public health.

\section{Supplementary information}

Supplementary information accompanies this paper at https://doi.org/10. 1186/s12884-019-2573-3.

Additional file 1: Figure S1. Flowchart sample.

Additional file 2: Table S1. Questionnaire contents and data collection tools, Pelotas 2015.

Additional file 3: Table S1. Questionnaire items and the antenatal care card variables.

\section{Abbreviations}

ANC: Antenatal care; Cl: Confidence interval; PABAK: Prevalence-Adjustedand-Bias-Adjusted Kappa; SDGs: Sustainable Development Goals

Acknowledgements

Not applicable.

Authors' contribution

LSMD, ARV and MFS were responsible for proposing the initial hypothesis and idea for study, designing the study, writing the first draft of the 
manuscript and analyzing and interpreting the data; ADB, FW, MRD, MFS and DGB were responsible for planning the cohort in which this study was carried out. All authors participated in the critical review of the final version of this manuscript, provided feedback on drafts, and approved the final version.

\section{Funding}

This article is based on data from the study "Pelotas Birth Cohort, 2015" conducted by the Postgraduate Program in Epidemiology at Universidade Federal de Pelotas, in collaboration with the Brazilian Public Health Association (ABRASCO). The 2015 Pelotas (Brazil) Birth Cohort is funded by the Wellcome Trust (095582). Additional financial assistance was provided by the Coordenação de Aperfeiçoamento de Pessoal de Nível Superior - Brasil (CAPES) Finance Code 001. Funding agencies had no role in study design, collection, analysis, data interpretation or manuscript writing.

\section{Availability of data and materials}

The dataset used in this study is available upon request.

\section{Ethics approval and consent to participate}

The antenatal follow-up of the 2015 Pelotas (Brazil) Birth Cohort Study was approved by the Superior School of Physical Education Research Ethics Committee from the Federal University of Pelotas under the protocol 522.064. After agreeing to take part in the study, women signed a written informed consent.

\section{Consent for publication}

Not applicable.

\section{Competing interests}

The authors declare that they have no competing interests.

\section{Author details}

'Post-Graduate Program in Epidemiology, Federal University of Pelotas, Rua Marechal Deodoro 1160 - Centro, Pelotas, Rio Grande do Sul 96020-220, Brazil. ${ }^{2}$ Center for Global Child Health, The Hospital for Sick Children and Department of Pediatrics, University of Toronto, Toronto, Canada.

Received: 6 March 2019 Accepted: 25 October 2019

Published online: 08 November 2019

\section{References}

1. Goulet F, Jacques A, Gagnon R, Racette P, Sieber W. Assessment of family physicians' performance using patient charts: interrater reliability and concordance with chart-stimulated recall interview. Eval Health Prof. 2007; 30(4):376-92. https://doi.org/10.1177/0163278707307924.

2. United Nations. Transforming our world: the 2030 agenda for sustainable development; 2015. Available from: https:/sustainabledevelopment.un.org/ content/documents/21252030\%20Agenda\%20for\%20Sustainable\%2 ODevelopment\%20web.pdf

3. Corser W, Sikorskii A, Olomu A, Stommel M, Proden C, Holmes-Rovner M. Concordance between comorbidity data from patient self-report interviews and medical record documentation. BMC Health Serv Res. 2008;85(8):1-9. https://doi.org/10.1186/1472-6963-8-85.

4. Okura Y, Urban LH, Mahoney DW, Jacobsen SJ, Rodeheffer RJ. Agreement between self-report questionnaires and medical record data was substantial for diabetes, hypertension, myocardial infarction and stroke but not for heart failure. J Clin Epidemiol. 2004;57(10):1096-103. https://doi.org/10.1016/ j.jclinepi.2004.04.005

5. St Sauver JL, Hagen PT, Cha SS, Bagniewski SM, Mandrekar JN, Curoe AM, et al. Agreement between patient reports of cardiovascular disease and patient medical records. Mayo Clin Proc. 2005;80(2):203-10. https://doi.org/ 10.4065/80.2.203

6. Tisnado DM, Adams JL, Liu H, Damberg CL, Chen WP, Hu FA, et al. What is the concordance between the medical record and patient self-report as data sources for ambulatory care? Med Care. 2006;44(2):132-40. https://doi. org/10.1097/01.mlr.0000196952. 15921.bf.

7. Hallal PC, Bertoldi AD, Domingues MR, da Silveira MF, Demarco FF, da Silva IC, et al. Cohort profile: the 2015 Pelotas (Brazil) birth cohort study. Int J Epidemiol. 2017;47(4):1048. https://doi.org/10.1093/ije/dyx219.

8. Byrt T, Bishop J, Carlin JB. Bias, prevalence and kappa. J Clin Epidemiol. 1993; 46(5):423-9. https://doi.org/10.1016/0895-4356(93)90018-v.
9. Landis JR, Koch GG. The measurement of observer agreement for categorical data. Biometrics. 1977;33(1):159-74. https://doi.org/10.2307/ 2529310.

10. Santos Neto ET, Leal M, Oliveira AE, Zandonade E, Gama S. Concordância entre informações do Cartão da Gestante e da memória materna sobre assistência pré-natal. Cad Saúde Pública. 2012; 28(2):256-266. DOI: https:// doi.org/10.1590/S0102-311X2012000200005

11. Zanchi M, Gonçalves CV, Cesar Juraci A, Dumith S. Concordância entre informações do Cartão da Gestante e do recordatório materno entre puérperas de uma cidade. Cad Saúde Pública. 2013;29(5):1019-28. https:// doi.org/10.1590/S0102-311X2013000500019.

12. Carvalho D, Novaes Hillegonda MD. Avaliação da implantação de programa de atenção pré-natal no Município de Curitiba, Paraná, Brasil: estudo em coorte de primigestas. Cad Saúde Pública. 2004;20(Supl 2):S220-30. https:// doi.org/10.1590/S0102-311X2004000800017.

13. McGovern PG, Lurie N, Margolis KL, Slater JS. Accuracy of self-report of mammography and pap smear in a low-income urban population. Am J Prev Med. 1998;14(3):201-8. https://doi.org/10.1016/50749-3797 (97)00076-7.

14. Pizarro J, Schneider TR, Salovey P. A source of error in self-reports of pap test utilization. J Community Health. 2002;27:351-7. https:/doi.org/10.1023/ A:1019888627113.

15. Heaman MI, Sword WA, Akhtar-Danesh N, Bradford A, Tough S, Janssen PA, et al. Quality of prenatal care questionnaire: instrument development and testing. BMC Pregnancy Childbirth. 2014;14:188. https://doi.org/10.1186/ 1471-2393-14-188

16. Silveira DS, Santos IS, Dias-da-Costa JS. Atenção pré-natal na rede básica: uma avaliação da estrutura e do processo. Cad Saúde Pública. 2001;17(1): 131-9. https://doi.org/10.1590/\$0102-311X2001000100013.

17. Coutinho T, Monteiro MFG, Sayd JD, Teixeira MTB, Coutinho CM, Coutinho LM. Monitoring the prenatal care process among users of the unified health care system in a city of the Brazilian southeast. Rev Bras Ginecol Obstet. 2010;32(11):563-9. https://doi.org/10.1590/S0100-72032010001100008.

18. Neumann NA, Tanaka OU, Victora CG, Cesar JA. Qualidade e equidade da atenção ao pré-natal e ao parto em Criciúma, Santa Catarina, Sul do Brasil. Rev Bras Epidemiol. 2003;6(4):307-18. https://doi.org/10.1590/S1415$790 \times 2003000400005$

19. Monteiro PB, Monteiro Filho MP, de Figueirêdo JT, Saintrain MVL, Bruno ZV, FHC C. Cytology-based screening during antenatal care as a method for preventing cervical cancer. Asian Pac J Cancer Prev. 2017;18(9):2513-8. https://doi.org/10.22034/APJCP.2017.18.9.2513.

20. Al Sairafi M, Mohamed FA. Knowledge, attitudes, and practice related to cervical cancer screening among Kuwaiti women. Med Princ Pract. 2009; 18(1):35-42. https://doi.org/10.1159/000163044.

21. Abiodun OA, Fatungase OK, Olu-Abiodun OO, Idowu-Ajiboye BA, Awosile JO. An assessment of women's awareness and knowledge about cervical cancer and screening and the barriers to cervical screening in Ogun state, Nigeria. IOSR-JDMS. 2013;10(3):52-8. https://doi.org/10.9790/0853-1035258.

22. Martins LFL, Thuler LCS, Valente JG. Cobertura do exame de Papanicolaou no Brasil e seus fatores determinantes: uma revisão sistemática da literatura. Rev Bras Ginecol Obstet. 2005;27(8):485-92. https://doi.org/10.1590/5010072032005000800009

23. Leung SSK, Leung I. Cervical cancer screening: knowledge, health perception and attendance rate among Hong Kong Chinese women. Int J Women's Health. 2010;2:221-8. https://doi.org/10.2147/IJWH.S10724.

24. Brasil Ministério da Saúde (MS). Secretaria de Atenção à Saúde. Departamento de Atenção Básica. Coordenação Nacional de Saúde Bucal. Braślia: MS: Diretrizes da Política Nacional de Saúde Bucal; 2004. Available from: http://bvsms.saude.gov.br/bvs/publicacoes/politica_nacional_brasil_ sorridente.htm

25. de Oliveira DMAS, Santos Iná S. Validade do auto-relato de diabete mellitus gestacional no pós-parto imediato. Cad Saúde Pública. 2009;25(2):251-8. https://doi.org/10.1590/S0102-311X2009000200003.

26. Solomon CG, Willett WC, Rich-Edwards J, Hunter DJ, Stampfer MJ, Colditz GA et al. Variability in diagnostic evaluation and criteria for gestational diabetes. Diabetes Care. 1996;19:12-6. https://doi.org/10.2337/diacare.19.1.12.

27. Ngo DL, Marshall LM, Howard RN, Woodward JA, Southwick K, Hedberg K. Agreement between self-reported information and medical claims data on diagnosed diabetes in Oregon's Medicaid population. J Public Health Manag Pract. 2003;9(6):542-4. https://doi.org/10.1097/00124784-200311000-00016.

28. El Fakiri F, Bruijnzeels MA, Hoes AW. No evidence for marked ethnic differences in accuracy of self-reported diabetes, hypertension, and 
hypercholesterolemia. J Clin Epidemiol. 2007;60(12):1271-12719. https://doi. org/10.1016/j.jclinepi.2007.02.014

29. Bush TL, Miller SR, Golden AL, Hale WE. Self-report and medical record report agreement of selected medical conditions in the elderly. Am J Public Health. 1989;79(11):1554-6. https://doi.org/10.2105/ajph.79.11.1554.

30. Miller DR, Rogers WH, Kazis LE, Spiro A, Ren XS, Haffer SC. Patients' selfreport of diseases in the Medicare health outcomes survey based on comparisons with linked survey and medical data from the veterans health administration. J Ambul Care Manage. 2008;31(2):161-77. https://doi.org/10. 1097/01.JAC.0000314707.88160.9C.

31. Mithoowani S, Celetti SJ, Ifan N, Brooks A, Mertz D. Inadequate documentation of urinary tract infection symptoms in the medical chart. Am J Infect Control. 2015;43(11):1252-4. https://doi.org/10.1016/.jajic.2015.07.037.

32. Dietz P, Bombard J, Mulready-Ward C, Gauthier J, Sackoff J, Brozicevic P, et al. Validation of self-reported maternal and infant health indicators in the pregnancy risk assessment monitoring system. Matern Child Health J. 2014; 18(10):2489-98. https://doi.org/10.1007/s10995-014-1487-y.

33. Liu J, Tuvblad C, Li L, Raine A, Baker LA. Medical record validation of maternal recall of pregnancy and birth events from a twin cohort. Twin Res Hum Genet. 2013;16(4):845-60. https://doi.org/10.1017/thg.2013.31.

34. Gresham E, Forder P, Chojenta CL, Byles JE, Loxton DJ, Hure AJ. Agreement between self-reported perinatal outcomes and administrative data in New South Wales, Australia. BMC Pregnancy Childbirth. 2015;15:161. https://doi. org/10.1186/s12884-015-0597-X

35. Stange KC, Zyzanski SJ, Smith TF, Kelly R, Langa DM, Flocke SA, et al. How valid are medical records and patient questionnaires for physician profiling and health services research? A comparison with direct observation of patient visits. Med Care. 1998;36(6):851-67. https://doi.org/10.1097/ 00005650-199806000-00009.

36. Luck J, Peabody JW, Dresselhaus TR, Lee M, Glassman P. How well does chart abstraction measure quality? A prospective comparison of standardized patients with the medical record. Am J Med. 2000;108(8):6429. https://doi.org/10.1016/s0002-9343(00)00363-6.

37. Molenaar EA, Van Ameijden EJ, Grobbee DE, Numans ME. Comparison of routine care self-reported and biometrical data on hypertension and diabetes: results of the Utrecht health project. Eur J Pub Health. 2007;17(2): 199-205. https://doi.org/10.1093/eurpub/ckl113.

38. Bowlin SJ, Morrill BD, Nafziger AN, Lewis C, Pearson TA. Reliability and changes in validity of self-reported cardiovascular disease risk factors using dual response: the behavioral risk factor survey. J Clin Epidemiol. 1996;49(5): 511-7. https://doi.org/10.1016/0895-4356(96)00010-8.

39. Goldman N, Lin IF, Weinstein M, Lin YH. Evaluating the quality of selfreports of hypertension and diabetes. J Clin Epidemiol. 2003;56(2):148-54. https://doi.org/10.1016/s0895-4356(02)00580-2.

40. Bergmann MM, Jacobs EJ, Hoffmann K, Boeing H. Agreement of selfreported medical history: comparison of an in-person interview with a selfadministered questionnaire. Eur J Epidemiol. 2004;19(5):411-6. https://doi. org/10.1023/b:ejep.0000027350.85974.47.

41. Gama H, Correia S, Lunet N. Effect of questionnaire structure on recall of drug utilization in a population of university students. BMC Med Res Methodol. 2009;9:45. https://doi.org/10.1186/1471-2288-9-45.

42. Rice F, Lewis A, Harold G, van den Bree M, Boivin J, Hay DF, et al. Agreement between maternal report and antenatal records for a range of pre and peri-natal factors: the influence of maternal and child characteristics. Early Hum Dev. 2007;83(8):497-504. https://doi.org/10.1016/j. earlhumdev.2006.09.015.

43. Troude P, L'Hélias L, Raison-Boulley AM, Castel C, Pichon C, Bouyer J, et al. Perinatal factors reported by mothers: do they agree with medical records? Eur J Epidemiol. 2008;23(8):557-64. https://doi.org/10.1007/ s10654-008-9268-9.

44. Hessol NA, Missett B, Fuentes-Afflick E. Lower agreement on behavioral factors than on medical conditions in self-reported data among pregnant Latina women. Arch Med Res. 2004;35(3):241-5. https://doi.org/10.1016/j. arcmed.2004.01.002.

45. Rohrbaugh M, Rogers JC. What did the doctor do? When physicians and patients disagree. Arch Fam Med. 1994;3(2):125-9.

46. Worster A, Haines T. Advanced statistics: understanding medical record review (MRR) studies. Acad Emerg Med. 2004;11(2):187-92. https://doi.org/ 10.1111/j.1553-2712.2004.tb01433.x.

47. Partin MR, Malone M, Winnett M, Slater J, Bar-Cohen A, Caplan L. The impact of survey nonresponse bias on conclusions drawn from a mammography intervention trial. J Clin Epidemiol. 2003;56(9):867-73. https://doi.org/10.1016/s0895-4356(03)00061-1.

48. Van Minh H, Oh J, Giang KB, Kien VD, Nam YS, Lee CO, et al. Multiple vulnerabilities and maternal healthcare in Vietnam: findings from the multiple indicator cluster surveys, 2000, 2006, and 2011. Glob Health Action. 2016;9(1):29386. https://doi.org/10.3402/gha.v9.29386.

49. Simkhada B, Van Teijlingen ER, Porter M, Simkhada P. Factors affecting the utilization of antenatal care in developing countries: systematic review of the literature. J Adv Nurs. 2008;61(3):244-60. https://doi.org/10.1111/j.13652648.2007.04532.x.

50. Olson JE, Shu XO, Ross JA, Pendergrass T, Robison LL. Medical record validation of maternally reported birth characteristics and pregnancy-related events: a report from the Children's cancer group. J Epidemiol. 1997;145(1): 58-67. https://doi.org/10.1093/oxfordjournals.aje.a009032.

\section{Publisher's Note}

Springer Nature remains neutral with regard to jurisdictional claims in published maps and institutional affiliations.
Ready to submit your research? Choose BMC and benefit from:

- fast, convenient online submission

- thorough peer review by experienced researchers in your field

- rapid publication on acceptance

- support for research data, including large and complex data types

- gold Open Access which fosters wider collaboration and increased citations

- maximum visibility for your research: over $100 \mathrm{M}$ website views per year

At BMC, research is always in progress.

Learn more biomedcentral.com/submissions 